\title{
千葉県茂原農学校の英書
}

\author{
一加藤忠治のこと一
}

小川原 清 江

\author{
I 序 \\ II 茂原農学校とその英書文献 \\ III 加藤忠治校長 \\ IV 茂原農学校の教育とその影響
}

$\mathrm{V}$ 結 び

附 録

1 茂原農学校英書目録

2 加藤校長履歷書

\section{I 序}

本論に入るに当って最初に，日本全体について明治の農業史を一憼します。明治政府は 所謂「富国（強兵）」の大斾をかざして，本邦の農業振興を計ったのですが，そうした努 カの中に, 日本英学史と関係の深いのは, 札幌農学校, クラーク他一連の米人教師のこと もありますが, 有名な薩摩辞書の作者, 前田正名が農商務省で勧農に努めたことも逸する ことができません。〔前田は, 明治 9 年, フランスで種苗収集, 10 年に： 7 年振りに帰国 すると，勧農局事務取扱，三田育種場長，内国勧業博御用倸，興業意見配布（17年），山 梨県知事, 農商務次官, 元老院議官, 全国農会幹事長, 雑誌「産業」発刊 (30年, 38号を 以て廃刊)，引退後も明治39年大日本農会顧問をしている(明治36年)，大正10年72才で逝 く (男爵, 正三位勲二等).」明治政府の農業指導方式は, この前田が立案したように海外 から種苗を輸入，牧畜も良種の輸入によりました。研究機関の体制は，東京・札幌の学校 を近代式農業を授ける場としたのですが千葉県の下総種羊場と内藤新宿の試験場は, 宮内 省に移管され，いかにも中途半端な感じがします。しかし，札幌・東京の農学校の卒業生 は, 明治32年以降全国各県の農学校や試験場に送りこまれて, 日本近代農業形成期に入り 
英 学 史 研 究 第 8 号

ました。勿論米作などの場合, この知識人の他に, 実地農業者（農豪, 老農）の存在も無 視できません。肥料など彼等独自の研究にまつものも多かったようです〔千葉県の場合, 奈良専二は，反収 8 石をあげ自己の経験に固執しています」。しかし，明治期に知識人が 在来農業に改良の気運を醸成した貢献は, 米作りの篤農の反目を外に見逃せないことはこ れから申上げる加藤の輸入本の scale をみただけでも判ります。明治20年11月, 駒場・札 幌農学校・東京農林学校の卒業生によって農学会が結成され，興農策を主張しました。丁 度, 前田の興業意見の出た後です。又, 政府は, 興業勧農のために全国勧業博覧会（明治 10年第 1 回, 34年10回）を開催したことは, 今日, 私達が想像する以上に大きな貢献をし ています。明治36年, 当局が出した「農事必行事項」で指示したものは, 1 - 5 米麦選種 他, 6. 果樹養虫, $7-8$. 桑園, 9. 堆肥, 10. 農具, 11. 牛馬耕, 12. 家禽, 13. 耕 地整理, 14. 産業組合に及んでおり, この指導を農商務省から地方官庁を通じて実施させ ました。こうした背景をふまえて, 千葉県におけるひとりの農業先駆者と, 約 200 冊の英 書が千葉県農業をどのように変えていったかということを考えてみたいと思います。

その農業先駆者とは，千葉県茂原市にある千葉県茂原農業高等学校の第 2 代校長であっ た加藤忠治であり, その英書とは, 同校がいまだに所蔵する農学及びその他の部門に関す る188部の英書であります。

加藤忠治は, 明治26年札幌農学校を卒業後, 明治34年茂原農学校の第 2 代校長として迎 えられ，精力的に農業教育及び英語教育に当たり，恐らくこの188部の英書から得た知識 をもとに，幾多の農業指導者を輩出し，千葉県農業を大きな転機に導いた人です。

当時, 千葉県農業は他の日本各地と同様に米と養虫にたよりきっており, 洋菜を中心に した近郊農業への脱皮は, この加藤忠治の校長就任後, しばらくしてょうやく始まるので す。

以下この188部の英書と千葉県農業とを関連させてその関係について, 又その推進者で あった加藤忠治について見ていきたいと思います。

III茂原農校とその英書文献

茂原農業高校の沿革をたどってみますと, 明治30年頃の日本国内における富国政策の一 
千葉県茂原農学校の英書

環として，即ち日清戦争に勝利はおさめたものの，国力の疲弊を憂える明治政府がとった 産業振興政策の具現として,各地方各県に実業学校設立を奨励したのでした。同校も,そう した政策の下に明治30年11月，千葉県における最初の実業学校として設立されたのです。

明治30年11月 千葉町（現在の千葉市）に千葉県簡易農学校として, 文部大臣より認可さ れ開校

明治32年 4 月 千葉県農学校と改称し, 甲種 3 か年制となる。定員 150 名。

明治32年11月 長生郡茂原町野巻戸に移転

明治 34 年 5 月 千葉県立茂原農学校と改称, はじめて卒業生 36 人を送り出す。 この年の 3 月に第 2 代校長として加藤忠治赴任。

大正10年：農業指導員養成所を併設。

昭和23年: 4 月 学則変更により, 千葉県茂原農業高等学校と改称。

昭和28年12月 茂原市上林, 現在の新校舎に移転。

明治30年 7 月の県341号達，[千葉県簡易農学校創立時予算]の資料によれば，校費 3,163 円64銭 1 厘とし，俸給1,068円，内訳校長540円，教員420円，書記108円と記録されていま す。いかに千葉県がその創設に力を入れていたか, ということは, 当時の佐倉中学校の予 算が600円だったことなどと比べると大体がうかがい知ることができるのです。県から多 額の費用を組み入れられ，当時他校に類をみないほど多くの外国の書物を買うことも認め られていたのですから。

その188部もの英書, 中にはドイツ語の簿記の本なども混じってはいましたが，これら の英書を内容によって分類しますと，10項目に分けられます。

\section{I 農学書 35 冊}

II 植物学書 18 冊

III 造園 - 園芸 - 森林学書 14 册

IV 動物学・獣医学・昆虫学 8 册

$\mathrm{V}$ 牧畜・酪農書 14 冊

VI 化学 (chemistry) 書 39 冊 


\section{英 学 史 研 究 第 8 号}

VII 科学. 数学. 物理学書 14 冊

VIII 教育・道徳書 16 冊

IX 社会・経済学書 18 冊

$\mathrm{X}$ 語学・文学書 12 冊

であります。リストアップしたものは，各項目別にアルファベット順にしてあります。こ れらの書物は, 明治34年起（加藤忠治赴任の時）【書籍台帳]（千葉県教育センター資料 室蔵）に毛筆書きで, 書名・著者名（カタカナで書いてある）購入年月日・購入先・代金 が詳細に記録されています。購入先は, 丸善が多く，記録は大正13年頃まで続けられてい ました。この台帳が記録を続けられた期間と加藤の在職期間がほぼ一致していることか ら，この貴重な英書の購入者が加藤であるといら裏付が得られたのです。

\section{III 加藤忠治校長}

茲に，加藤忠治という先覚者的人物に眼を向けてみましょう。

加藤忠治は, 明治 3 年 6 月, 愛知県名古屋市岩井町の, 三河武士の家柄に生まれ, 明治 26年札幌農学校を卒業しています。卒業後は, 高知県尋常中学校教諭, 同県師範学校教員 を兼任し, 3 年後の明治30年和歌山県第 2 尋常中学校に, 翌31年には, 杤木県 蕁 常中学 校, 32年には若冠28才で山形県啡常中学校長として赴任し, 山形中学校在任 2 年を経て, 千葉県の招きで, 34 年 3 月に千葉県農学校長として, 年俸 1,080 円の待遇で着任しました。

明治32年実業学校令が発布され, 農（工商）業に徒事することを須要なる教育を授ける こととしていたのと関連しているものと思われます。

翌35年には千葉県技師高等官 7 等を以って処遇され，それ以後大正 15 年 56 才で，喉頭ガ ンのため現職のまま病没するまで 26 年の間, そのほとんどの生涯を茂原農高の発展のため に捧げられました。大正13年には, 勲四等瑞宝章・高等官三等の栄誉に浴しました。この 頃, 前年の大正12年関東大震災による被害復興のための, 心労や無理が続き健康を著しく 害されたようです。現役で病没した大正15年までの間に輩出した門下生は約 1,500 名を数 え, 県下の農業界はもとより, あらゆる分野へ, 優秀な指導者を巣立たせたのでした。

ところで，当時にしては，異常な量とも思える188部もの英書を加藤校長が購入してい 
千葉県茂原農学校の英書

たという事实に関して，加藤校長が，札幌農学校卒業生であったという点が大きな意味を 持つと思うのです。札幌農学校卒業生の多くが，農学士となる人よりも，英学士として活 躍した英才が多かったように, 加藤も又, 農学士としての業績に加えてその達者な英語力 を, 当時としては辺境の地茂原においていかんなく発揮したのです。当時の札幌農学校に ついてちょっとふれますと(池田哲郎氏の研究報告第85号に詳しく述べられていますが), 加藤校長も，クラークのフロンティア精神を受けつぎ，感化されたものと思います。 加藤が，札幌農学校に在学したのは，明22 25年の頃であるが，その頃，同校は漸くア メリカ人教授に代って，邦人教授を以てする傾向に入っていました。

佐藤昌介は, ジョンズ・ホプキンス大学で農政学を研究して帰朝。19年 8 月母校教授,

27 年 4 月校長となる。

宮部金吾（ハーバート）は，22年帰国，植物学教授に

渡瀬庄三郎は, ジョンズ・ホプキンス大学に留学, 19 年 7 月に帰道。13年つとめて 32 年

東大理科大教授に

吉井豊造（18年: 7 月駒場卒, 北海道技師）は20年 3 月化学担当教授になる。

22 年から，教課目に，独語が入り，この頃海外留学を命ぜられた広井勇（専門は土木工 学・物理・数学）・新渡戸稲造（経済学・歴史）はそれぞれジョンズ・ホプキンスから， ボン・ペルリン・ハレの三大学に渡り, 農業経済学, 農業統計学, 農業法規の研究をした のです。この辺は, 米国農業からドイツ農業への転換がみられます。しかし，札幌の伝統 には，永く開拓使時代の，アメリカ風の気魄が残っていました。いわゆる学風というもの を，有馬頼㗬（43年東大農科）は次の通り述べています。

『駒場の卒業生は，役人（農林省，地方庁）になるか，農学校の先生になるかで，自分 で農場を経営したり，海外に雄飛する者は，稀でした。これに反し札幌の卒業生は，朝鮮 -台湾・南米に又，実業界・政界に入る人も多く，異色ある人物が沢山出ました。（例え ば, 新渡戸稲造, 早川鉄弥, 千石与太郎, 有島武郎その他武信由太郎, 頭本元貞, 岩崎行 親, 斎藤祥太郎, 内村鑑三，菅菊太郎，蔵原惟郭，佐久間信恭等です。）

これは駒場が，17万坪といっても武蔵野の一隅にすぎない Campus だったのに，札幌 農学校の方は, 北海道の雄大さを背景に持つ環境と学風が重大な関係を持っているのだと 
英 学 史 研 究 第 8 号

思います。』（有馬「七十七年の回想」昭和 $38 ， 122 \sim 123$ 頁）

加藤の在学中に, 札幌農学校に在職した外人教師は, ブルックスの後任に, マサチュセ ッツ農大出身の, Authur Anber Brigram（21年1月～26年10月）が在職, 農学, 植物 学を担当したが，この人の後，外人専門教師は全く跡を絶つことになったのです。

加藤の在学中の教授科目は, 日本経済, 歴史, 農業経済, 山林学, 昆虫学, 農政, 地方 制度, 植民政策, 農業史などがあり, 往年の英文学史などは削られ, 英語関係は第一年初 級のみに課せられ，22年 9 月にはドイツ語に多くの時間が加えられ, 農業科の農業と獣医 学を減じ, 農芸化学, 植物学, 動物学, 昆虫学等の時間を増しています。20年に, 農業実 習を, 減じたのは, 校園と私企業の競争を避けるためで, 英学の減少は, 邦語による邦人 教師の英語授業が増加したためであります。

このような札幌農学校が, 農業教育のみならず, 英語教育・精神教育を重んじたよう に，茂原農学校における彼の教育方針も，同じようなものであったと思われます。 加藤忠治を直接間接に知る人々が, 彼を語ることばは, 「学者というより, 進取の精神 に富んだ豪放否落, 自由闊達な徳育家であった」ということです。彼を, 「千葉県の新渡 戸稲造」と呼ぶ人々もいます。札幌農学校卒業生という経歴が，その後の加藤の豊かな精 神生活, 数々の業績をもたらしたのだと言っても過言ではありません。又つけ加えます と, 加藤の妻ヤスは, 熱心なキリスト教信者で, 布教や教会関係への奉仕を惜しまず, 加 藤自身は，キリスト教には消極的であったようですが，妻の日常には大変寛大であったと いうことです。

英語教育についてですが, 校長自ら, 英語の授業を担当し, 教壇に立ち, 他の中学校よ りもレベルの高い授業にして，生徒の英語力増進に力を入れました。

明治35年度使用教科書一覧[千葉県教育百年史]によると，スウイントン氏読本 1,2 , 3，4 と記録が残され，又茂原農校での英語授業時数表 [千葉県教育百年史]によれば, 国語, 化学, 物理, 数学をしのいで英語の授業時数が一番多くなっています。一年生で週 4 時間, 読書, 習字, 二年生で週 4 時間, 読書, 文法, 三年生で週 5 時間, 読書・作文と なっています。当時の非常中学生は, 茂原農学校の学生に英語を教えてもらったといらこ とです。農業経営としては未だ稲作り, 養蚕といら未開発といらか多角化されていない日 


\section{千葉県茂原農学校の英書}

本農業の将来を見こして, 農業の発展は海外の技術に依存してこそという信念のもとに, 英語教育の必要を㤳っていたことは，加藤校長がいかに先見の明があったかということを 物語っていると思います。

又加藤校長輩下には，札幌農学校出と東京帝大出の新進気鋭の青年教師が多く集まり， これらの英書から得た知識を授業にとり入れ，学生たちも他校にはみられない授業を受け られることに誇りをもっていました。

加藤校長は, 又大変な読書家であり, 校長室の机の傍には, ガラス張りの回転式本棚を すえ, いつもこれらの英書を手に，部下の教師達に，授業の参考にすることをしきりにす すめていたということです。特に，農芸化学の分野に造詣が梁く，これに関する論文を書 こうと志したとも伝えられます。残念なことに加藤校長は志をなかばにして完成をみない まま病気で他界されてしまいました。

「加藤校長の講話や記事は, 幅広く, 話題が豊富で, 昔の話, 外国の逸話, 歴史物語あ るいは社会の動きを多くとり入れ，その中には必ず人間としてのあり方が説かれていた」 と思い出を語ってくれた人もいました。「灯台の捨て石になれ」とは加藤校長がよく口に したことばだそうです。

又森田茂原農高前校長によれば，加藤校長は「真実な人間づくり」「人格の養成」を最 も大切な柱と考え，さらに「農業開拓の精神」を植えつけたということです。明治30年代 の校友会々誌によせた記事には, 中国の偉人, 曾国藩の内面的精神生活について「青年 は，敬の心をもたねばならぬ。人閒の願わしい一切の美果を敬に帰する」と述べ，更にゲ 一テの小文をも引用し「常に衷心より他の偉大なものに感激し不断に自己の弱小をかえり みなければならぬ」と書いています。

それから札幌農学校の実習方式は茂原の場合も取り入れられ，1人 1 アール (30坪) 担 当制が実施されています。

このように優れた徳育家である加藤校長の修身教育について，卒業生が忘れ得ない思い 出の数々, 多くのエピソードについて話してくれました。当時の学生は, 千葉県下 は勿 論, 他府県からも又遠くは中国や朝鮮からの留学生もいたということです。

生徒は, 現有耕地三反歩以上の農業経営者の子弟で, 郡農会や町村長の推蔦のある者に 
英 学史 研 究 第 8 号

限るという古い記録が残っていますが，かなり広い地域の有産，中農以上の階級の子弟で 英才が集っていたのです。従って学校は, 全寮制で寄宿舎生活は厳格で質実剛建のいわゆ る「茂農魂」をつくり上げ, さらに加藤先生の不撓不屈, 進取の精神をも加え, 愈々徹底 したのです。

先生は時々, 馬に乗ってこの寄宿舎の見廻りをし, ある時, 生徒達と談笑に更けるあま り消燈時間をも忘れ，馬に乗ったまま廊下を走り去ったというエピソードも残していま す。素行が悪く退学寸前の, いわゆる不良学生などには郷里の親にも優る深い愛情で接 し，先生の家庭に何日でもひきとり，寝食を共にして彼等が立ち淔るまでめんどうをみた といらことです。

家庭は, 当時小さい一男一女とクリスチャンであったヤス夫人の 4 人暮しでした。

このような愛情ある心のふれあいに, 大方の悪童達も心をひきしめ, 温順な人柄となり 生涯, 感謝を忘れずにいるのです。このような話から, 私達の心にまで偉大な教育家, 加 藤忠治校長のイメージが焼きつけられます。

先生の心の糧ともなったのではないかと思われる英書を, 一応この旧蔵リストからとり あげてみますと，

NO. 149 Gould

NO. 150 Janet

NO. 154 Pestalozzi

NO. 157 Thorndike

NO. 158 Van Dyke

NO. 171 Ogg

NO. 186 Seignobos

などであろうと思います。

IV 茂原農校の教育とその影響

では最後に茂原農学校で行なわれた実業教育について述べます。

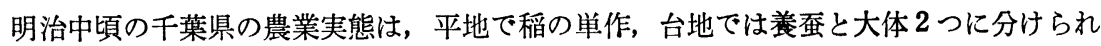




\section{千葉県茂原農学校の英書}

る程度のものでした。このような情況下に, 国策と, 県の農業政策とが相俟って大きなバ ックアップとなり, 茂原農学校に寄せる期待は多大なものだったのです。従って, 茂原農 学校の帯びた重大な使命・即ち先進的技術を身につけた青年の育成を果たすべく行なわれ たのが，実習を伴う実業教育だったのです。

農業実習は, 明治36年12月学事事跡報告にらたわれてあるように「生徒ヨシテ専ラ農業 的趣味を解セシメ, 且ツ卒業後好ンデ実業ニ就カントスルノ意思 養成シ兼テ之ガ経営設 備ヨナシ得ルノ能力ヨ涵養セントスルニアリ」との趣旨のもとに, 修身科と共に, 大変重 要視されていたのです。実習農場での実地教育は, 生徒 2 人 1 組で 1 アールほどの農場を 分担し, 蔬菜を主に, 収量収支計算をし, それが学業成績になったという教育方法でし た。

明治30年から明治41年に記された「官庁公文書綴」による〔虫種製造その他の実習施設 状況】をたどってみますと, 明治34年養鶏や養豚がはじめられ，40年には畜舎新築落成し たことがわかります。これが酪農の芽生えの時期だったと思われます。農業に関しては当 然のことながら, 理科関係を含めて, 実験施設のいずれもが, 当時の学校としては最新の ものであり，設備に多額の費用をかけたといら点でも，加藤校長のなみなみならぬ熱意を うかがい知ることができるのです。

〔明治34年度共同実習成績〕（「千葉県教育百年史」より）によれば．蔬菜類の中にチシ ヤ, 甘藍などの洋菜が栽培され, 収穫簿に, 甘藍10個 8 円18銭から10円 20 銭, チシャ 1 把 0.5銭とわずかながら商品化されたことが記されています。

新しい知識や，新しい技術の習得の結果を交換するために明治政府の主催した勧業博覧 会にも出品する許可を得ています。

〔明治35年第 5 回内国勧業博覧会出品目録](「千葉県教育百年史」掲載)の記録が残さ れています。それによると, 学芸之部, 教育之部, 動物之部, 農産物之部と分けられ, 動 物之部において, 飼育試験用豚 4 頭, 千葉県バークシャ 2 頭を出品していることは興味哚 いところです。そして米ゔくりの田と，桑畑の広がる千葉県の農地に，キャベッ，カリフ ラワー,トマト.アスパラガスの洋菜や, 桃・ぶどう・いちご・柑橘類などの果樹を植え させ実らせたのは，他でもない加藤校長の買い集めた英書だったといえましょう。 
英 学史 研 究 第 8 号

当時,わが国ではまだ普及していなかったこれらの洋菜や果樹の栽培法や経営法は, 外 国文献にたよる以外に方法はなかったのです。

従ってこれらの原書は, 千葉県農業教育の礎であり，新技術導入の源であった，非常に 貴重な文献といえるのです。

以上申しました実習教育に寄与したと思われる英書を一応推測して，とりあげてみます と,

11. Fluton, James Alexander

(Peach culture)

35. Allen

(Cabbage, cauliflower, and allied vegetables)

45. Hexamer

(Asparagas, its culture for home use and for market)

47. Lelong

(Culture of the citrus in California)

55. Barry

(Fruits garden)

76. Curtis

(Horses, cattle, sheep and swine)

79. Fream

(The complete grazier and farmers' and cattle breeders' assistant forming a compendium husbandry.)

83. Long

(The book of the pig)

87. Root

(Quinby's new bee-keeping)

88. Shaw

(The study of breeds in America, cattle, sheep and swine) 


\section{千葉県茂原農学校の英書}

\section{Husman}

\section{(Grapes growing and wine making)}

などが揚げられると思います。（書名左の番号は末尾茂原農高英学書目録参照）

農業実習で試みられた蔬菜, 果樹栽培, 酪農において実際の千葉県農業史と照らしあわ せ，加藤忠治の功績を実証してみました。

これは農業史といら分野でありますから，私ども門外漢には，ほんの一部しかのぞき見 ることはできませんでしたが, 千葉県庁農業改良課, 農産課の方々のご協力で, ある程度 の裏付はなされました。

先ず, 洋菜では, 明治28年頃, 万里小路通房伯爵が, 千葉県安房郡北条町 (現在の館山 市）に別荘を建て, その庭にガラスフレームを作り園丁の福羽逸人をフランスへ留学させ 促成栽培技術を習得させて, 実験的に栽培したのにはじまります。レタスなどは明治35年 頃, はじめて鋸南町勝山に姿をみせ, 大正初期にパセリ，カリフラワー等と共に京浜地区 へ出荷され, 鉄道敷設時期と相まって, 出荷は激増し, 愛知県と競い洋菜県の名を全国に 高くしました。

柑橘類についても, その歴史は明治20年勧業博覧会から 1 本 1 円の苗木を 3 本購入, 房 州の地に植えつけたことから始まります。35年には農林省の園芸試験場ができ, 外国品種 も導入研究され, 房州みかん栽培の指導が本格化され, 大正 5 年には柑㰌組合連合会が組 織され, 郡農会は, 苗木購入, 肥培管理, 病虫害防除等の奨励事業を行なっています。

いちごも，千葉県に最初に入ったのは，明治35年，フランスやアメリカから苗が来たの は市川市でした。その後市川いちごとして千葉県の代表作物の時代がありました。このよ らに千葉県農業の歩みを考えてみますと, 実験段階の時期, 改良期, 増産期と重なり, 千 葉県唯一の農学校長, そして千葉県農業技師の加藤忠治は言うに及ばず, その息のかかっ た多くの卒業生が何らかの形で，千葉県農業に貢献したことは疑ら余地もありません。加 藤忠治は県下各地へ農事講演に講師として招かれ，精力的に歩かれたとの話も数々聞きま した。そこでは農業経営のみならず，農業開発の面にも尽力され，赴任後数年にして，千 葉県下10数か所にある郡農会の所長をはじめ, 農業指導者の大多数は茂原農学校卒業生で 占めるという時代がやってきたのです。現在の千葉県農業の特長である蔬菜栽培を主流と 
英 学 史 研 究 第 8 号

する近郊農業県としての胎動が，ちょうどこの頃に始まったと言えましょう。ついでなが ら,レタス，パセリは日本一の産地（昭和41年）となり,トマト，いちご，甘藍なども全 国有数の生産県となっていることを申し添えておきます。

以上述べましたよらに，国や県の政策に支えられた開校当時から，全国有数の近郊農業 千葉となった現在に至るまで，茂原農校が果たした役割の重要さは言うまでもありませ ん。

千葉県の実業教育, 農業教育は加藤忠治校長と188部の英書によって始められたという ことができます。

以上不完全ではありますが，このレポートをまとめながら，加藤校長の教育にともした 灯を，私たちは過去のものとしてはならないのではないかと感じました。つまり現在の知 識偏重教育に疑問を持つべきではないかといらことです。私たちは，これからの教育課の 題として, 又日本の産業発達の課題として, 加藤校長の指導された実習教育というものを もう一度考えてみたいと思います。

このレポートをまとめるにあたり, 色々ご教示, ご協力くださった方々の芳名を記し厚 くお礼申しあげます。（敬称喃）

桑垣伝司（茂原農高教諭）茂原市渋谷596

值藤寿二（千葉県農業事務局々長）千葉市松波町 3-4-17

鶴岡善衛（茂原農高第 9 代校長）茂原市三貫野 1590

島田貞一（元船橋図書館長）船橋市藤原町 3-427-55

藤沼 享 (旧茂原農高教諭, 元犢村々長) 千葉市長沼13

森田誠一（茂原農高第 8 代校長）船橋市前貝塚723

森川 隆 (内科医) 茂原市本納町粟生野971

飛田七蔵（元安城農林高校々長）愛知県岡崎市伊賀町 4 の35

吉野正明 茂原市早野新田91 


\section{千葉県茂原農学校の英書:}

\section{交 献 (敬称略)}

著者

書籍台帳

明治34年起

千葉県立茂原農業高校

記念誌

昭和 41 年

千葉県教育委員会

千葉県教育百年史

$\begin{array}{ll}\text { 史料編 } & \text { 昭和 } 47 \text { 年 } \\ \text { 通史編 } & \text { 昭和 } 48 \text { 年 }\end{array}$

椎野善助

茂原市東南部発達史

千葉毎日新聞社

房総人名辞書

明治 42 年

茂原市史編纂委員会

茂原市史

長生郡農会

長生郡農会報第 4 号

明治36年

池田哲郎

北海道英学史英研「報告」85号 昭和 42 年

千葉県庁農林部

農業千葉

昭和 41 年

昭和46年

祖田 修

前田正名 吉川弘文館

昭 48

斎藤之男

日本農学史 大成出版社

昭43 